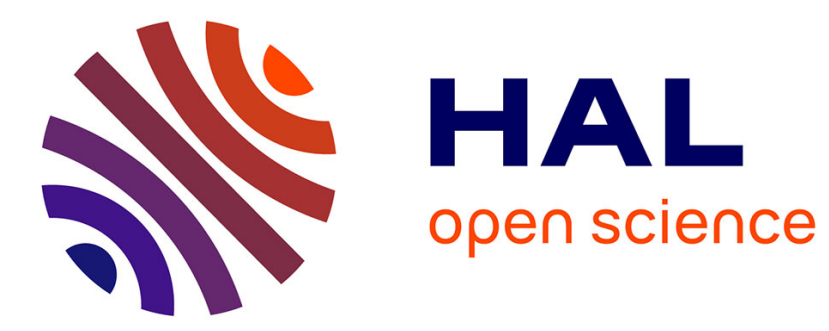

\title{
Follow-up study of four cases of pervasive refusal syndrome
}

Suzy Guirguis, Corrine Reid, Sushma Rao, Victoria Grahame, Carole Kaplan

\section{To cite this version:}

Suzy Guirguis, Corrine Reid, Sushma Rao, Victoria Grahame, Carole Kaplan. Follow-up study of four cases of pervasive refusal syndrome. European Child and Adolescent Psychiatry, 2011, 20 (5), pp.271-274. 10.1007/s00787-011-0169-1 . hal-00684397

\section{HAL Id: hal-00684397 https://hal.science/hal-00684397}

Submitted on 2 Apr 2012

HAL is a multi-disciplinary open access archive for the deposit and dissemination of scientific research documents, whether they are published or not. The documents may come from teaching and research institutions in France or abroad, or from public or private research centers.
L'archive ouverte pluridisciplinaire HAL, est destinée au dépôt et à la diffusion de documents scientifiques de niveau recherche, publiés ou non, émanant des établissements d'enseignement et de recherche français ou étrangers, des laboratoires publics ou privés. 


\section{Title page}

FOLLOW-UP STUDY OF FOUR CASES OF PERVASIVE REFUSAL SYNDROME (PRS)

Suzy Guirguis MBBS MRCPsych

Corrine Reid, MBBS MRCPsych

Sushma Rao MB BS MRCPsych

Victoria Grahame DClinPsych

Carole Kaplan MB ChB FRC Psych FRCPCH

Corresponding author:

Dr Victoria Grahame

Fleming Nuffield Unit

Burdon Terrace

Jesmond

Newcastle upon Tyne

Tel: 01912196440

victoria.grahame@ntw.nhs.uk

Acknowledgement Paragraph

We wish to thank the multidisciplinary in-patient team for their invaluable assistance, and all the families involved for giving their consent to be included in this case series.

Financial Support

Research time as contracted by NTW NHS trust was used in order to complete this project.

\section{Abstract}

The term Pervasive Refusal Syndrome was first mentioned in a paper detailing a sample study of four children by Bryan Lask and colleagues in 1991. This article presents a sample of four children diagnosed with Pervasive Refusal Syndrome, three girls and a boy, seen within a specialist NHS inpatient unit in the North East of England, and describes the main features presented. The main focus of the article will be on long term prognosis and outcome in relation to day to day functioning and activities. Each of the cases has been followed up once at an interval of between 3 and 16 years after discharge, and the outcomes are presented here. Results suggest that two of the young people with PRS made a complete recovery in the long term, that one was impaired by anorexia nervosa at follow-up, and the remaining young person was reluctant to be interviewed, so it is unclear how well she has maintained her initial discharge recovery.

\section{Key words}

Pervasive Refusal Syndrome, CAMHS, In-patient treatment, Withdrawal 


\section{INTRODUCTION}

Pervasive Refusal Syndrome (PRS) was first described by Bryan Lask and colleagues in 1991 [2], as a rare condition affecting young people. The patients displayed a wilful refusal to eat, drink, talk, and in some cases even move. Thompson and Nunn (1997) [7] have proposed specific diagnostic criteria (Table 1).

Examination of the literature suggests potential overlap between PRS and other psychiatric conditions. The most common differential diagnoses, identified by Jaspers and colleagues in their review, were Depression (54\%), Somatoform disorder (42\%), Anxiety disorder (29\%), and Eating disorder (17\%). However none of these diagnoses account for the full range of PRS symptoms, particularly the active resistance to help which is a distinguishing feature [1].

A literature review by Jaspers et al (2009) [1] identified only 15 relevant articles, indicating little has been written about PRS. Similarly our literature search yielded 17 relevant articles published between 1991 and 2010. However both reviews included cases of Depressive Devitalisation. This is thought to be a distinct refusal disorder that relates specifically to asylum seeking children (see Von Folsach, and Montgomery, 2006) [3].

Jaspers et al (2009) suggests that PRS most often affects girls, between 7-15 years, mean age 10.5 years, although our review identified a 4 year old male with possible PRS [6].

The main objective for this paper is to assess prognosis and outcome for a group of patients diagnosed with PRS who have been treated within a specialist inpatient unit. This follow-up data will provide valuable information, as the extreme rarity of PRS suggests that only a few cases will be treated each year. There are no published long term follow-up studies, and only a few studies have examined immediate outcome [1].

\section{METHOD}

\section{Settings and Participants}


All young people in the review were previously seen within a specialist NHS inpatient unit between 1989 and 2004. All young people identified were confirmed as meeting diagnostic criteria for PRS during their admission by a Consultant Child and Adolescent Psychiatrist, who confirmed the lack of any other explanatory psychiatric diagnosis, following physical investigations by paediatricians, to rule out possible organic causes.

\section{Procedure}

The project was supported by NHS Trust Chief Executive, following which consent to contact each young person was obtained.

Study participants were selected for follow-up based on a case note review. Background information was collated onto a pro-forma to confirm diagnostic criteria, as suggested by Thompson and Nunn (1997) [7] (Table 1). All confirmed cases were then coded on the basis of their symptomatology, and aetiological factors as suggested by the literature (Table 2).

"Table 1"

"Table 2"

The four confirmed cases were then contacted by post asking whether or not they were willing to participate in a follow-up telephone conversation. Following receipt of consent, interviews were conducted using a semi-structured questionnaire focusing on present functioning in the following areas:

- Eating and Weight.

- School attendance and educational achievement.

- Employment.

- Socialising and Relationships.

- Accommodation.

- Life Style and Health Issues. 


\section{RESULTS}

The current follow-up review identified one boy and three girls who were diagnosed as having PRS while attending the unit. They each had a psychiatric hospital admission of between 1 and 30 months (Table 3 ).

In terms of the current follow-up it appears that cases 1 and 2 have made consistent progress in their recovery, at 13 and 4 years later respectively. In terms of their functioning at follow-up both have made good progress academically, and are engaging in appropriate day to day activities with no concerns arising regarding their physical or mental health. On the other hand, Case 3 now fits a more typical anorectic picture. She currently relapses into episodes of anorexia with major concerns regarding her physical and mental health. In her case PRS occurred against a background of somatisation and suspected sexual abuse. Case 4 made considerable progress in socialisation, communication, weight gain and mobilisation following her initial discharge, but declined to participate in the follow-up. She stated that she "just wants to get on with her life" but said that we could contact the community nurse at her GP practice. Therefore only basic information was gathered.

In addition to their refusal behaviour in various domains a number of other overlapping presenting features were noted. At the time of presentation all four children were living with their biological parents. All were aged twelve and had one older sibling, and all but one had a family member with a serious psychiatric illness. Case 2 had a maternal aunt diagnosed with schizophrenia; Case 3 had grandparents who were both diagnosed with a depressive illness, and Case 4 had a father with history of a depressive illness. The mothers of two of the patients had an overprotective relationship with their children.

\section{DISCUSSION}

These results are comparable with the review undertaken by Jaspers et al (2009) [1] which indicated that most children with PRS make a full recovery (67\% of cases), although it was also reported that some make only a partial recovery ( $25 \%$ of cases), or are prone to relapse 
(4\%), while other studies do not report any follow-up prognosis (4\%). Thompson and Nunn suggest that most young people with PRS will require psychiatric hospital admission for more than a year [7]. Jaspers et al [1] suggests the average duration of therapy is 12.8 months. The average duration of our four cases was 15.25 months. However there is a reported case of complete recovery following inpatient treatment of only 2-8 weeks [7].

\section{CONCLUSION}

To our knowledge, this is the longest follow-up study of young people diagnosed with PRS. It is also one of the few studies to report a male case. The study is limited by the small number of cases identified, the retrospective nature of the review and the depth of information contained in the case notes. The results suggest that two of the three young people with PRS who participated in the interview made a complete recovery in the long term, and that the other was impaired by anorexia nervosa at follow-up. 


\section{REFERENCES}

1. Jaspers, T. Hanssen, G, M, J, Van der Valk, J, A, Hanekom, J, H Van Well, G, Th, J, and. Schieveld, J, N. M. (2009) Pervasive refusal syndrome as part of the refusalwithdrawal-regression spectrum: critical review of the literature illustrated by a case report, European Journal of Child Adolescent Psychiatry, 18(11): 645-651

2. Lask, B., Britten, C., Kroll, L., Magagna, J. \& Tranter, M. (1991) Children with pervasive refusal. Archives of Disease of Childhood, 66:866-869.

3. Lyngå von Folsach, L, \& Montgomery, E, (2006) Pervasive Refusal Syndrome among Asylum-seeking Children, Clinical Child Psychology and Psychiatry, Vol. 11, No. 3, 457473

4. Nunn KP, Thompson SL. (1996). The Pervasive Refusal Syndrome: Learned Helplessness and Hopelessness. Clinical Child Psychology and Psychiatry. 1(1):121-32.

5. Nunn KP, Thompson SL, Moore SG, English M, Burke EA, Byrne N. (1998) Managing pervasive refusal syndrome: Strategies of hope. Clinical Child Psychology and Psychiatry, 3(2):229-49.

6. Taylor S, Dossetor D,R, Kilham H, Benard E. (2000) The youngest case of pervasive refusal syndrome? Clinical Child Psychology and Psychiatry 5(1): 23-29

7. Thompson S, L, Nunn K,P. (1997) The pervasive refusal syndrome: The RAHC experience. Clinical Child Psychology and Psychiatry 2(1): 145-165 
Table 1: Diagnostic Criteria as suggested by Thomson and Nunn (1997).

- Presentation with clear food refusal and weight loss

- Social withdrawal and school refusal

- Partial or complete refusal in two or more of the following domains

- Mobilization - for example, reluctant to mobilize and will not mobilize unless assisted to do so, or has to be carried

- Speaking - for example is selectively mute or completely mute

- Attention to self care- for example refuses to wash or toilet without the assistance of another person.

- Active and angry resistance to acts of help and encouragement

- There is no organic condition that accounts for the severity or degree of the symptoms.

- There is no other psychiatric condition which could better account for the symptoms.

Table 2: Background comparison of four cases with features of refusal.

\begin{tabular}{|l|l|l|l|l|}
\hline & Case 1 & Case 2 & Case 3 & Case 4 \\
\hline Age (years) & 12 & 12 & 12 & 12 \\
\hline Gender & Male & Female & female & Female \\
\hline $\begin{array}{l}\text { Family composition: Living at home } \\
\text { with biological parents }\end{array}$ & & + & + & + \\
\hline Number of Siblings & 3 & 3 & & \\
\hline Birth Order & 2 & 2 & 2 & 2 \\
\hline Pre-morbid personality high- & & & Shy \& & Shy \& \\
achieving, perfectionist, \\
conscientious
\end{tabular}




\begin{tabular}{|l|c|c|c|c|}
\hline Psychiatric history of child & - & - & + & - \\
\hline $\begin{array}{l}\text { Family member with psychiatric } \\
\text { history }\end{array}$ & - & + & + & + \\
\hline $\begin{array}{l}\text { Overly close mother-child } \\
\text { relationship/over-involvement }\end{array}$ & + & - & - & + \\
\hline Known Stressors & Bullying & - & $\begin{array}{c}\text { Suspected } \\
\text { abuse }\end{array}$ & - \\
\hline
\end{tabular}

Table 3: Admission comparison of four cases with features of refusal.

\begin{tabular}{|c|c|c|c|c|}
\hline Features & Case 1 & Case 2 & Case 3 & Case 4 \\
\hline Food refusal and weight loss & + & + & + & + \\
\hline Social withdrawal and school refusal & + & + & + & + \\
\hline $\begin{array}{l}\text { Partial or complete refusal in two or } \\
\text { more domains: mobilisation, } \\
\text { speaking, attention to self care }\end{array}$ & + & + & + & + \\
\hline $\begin{array}{l}\text { Active or angry resistance to help or } \\
\text { encouragement. }\end{array}$ & Not Known & + & + & + \\
\hline No organic cause & + & + & + & + \\
\hline No other psychiatric illness & + & + & + & + \\
\hline $\begin{array}{llll}\text { Approx Length of } & \text { Admission } \\
\text { (Months) } & & & \end{array}$ & 12 & 1 & 18 & 30 \\
\hline Outcome on discharge. & + & $\begin{array}{c}\text { Transferred } \\
\text { to a unit } \\
\text { nearer } \\
\text { family } \\
\text { home }\end{array}$ & + & + \\
\hline
\end{tabular}


Table 4: Follow-up comparison of four cases with features of refusal.

\begin{tabular}{|c|c|c|c|c|}
\hline Features & Case 1 & Case 2 & Case 3 & Case 4 \\
\hline $\begin{array}{l}\text { Follow-up period in years } \\
\text { following initial discharge }\end{array}$ & 13 years & 4 years & 3 years & 16 years \\
\hline $\begin{array}{l}\text { Restoration of eating and } \\
\text { healthy weight. }\end{array}$ & + & + & - & Not Known \\
\hline $\begin{array}{l}\text { Participates in age } \\
\text { appropriate social } \\
\text { opportunities. }\end{array}$ & + & + & - & Not Known \\
\hline $\begin{array}{l}\text { School attendance and } \\
\text { educational achievement }\end{array}$ & + & + & - & Not Known \\
\hline $\begin{array}{l}\text { Recovery in mobilisation, } \\
\text { speaking, attention to self } \\
\text { care }\end{array}$ & + & + & + & + \\
\hline $\begin{array}{l}\text { Age appropriate living } \\
\text { arrangements. }\end{array}$ & + & + & - & Not Known \\
\hline $\begin{array}{l}\text { Active or angry resistance } \\
\text { to help or encouragement. }\end{array}$ & - & - & + & Not Known \\
\hline Other psychiatric illness & - & - & + & Not Known \\
\hline
\end{tabular}

